\title{
O percurso de uma alfabetizadora: formação e
} profissão

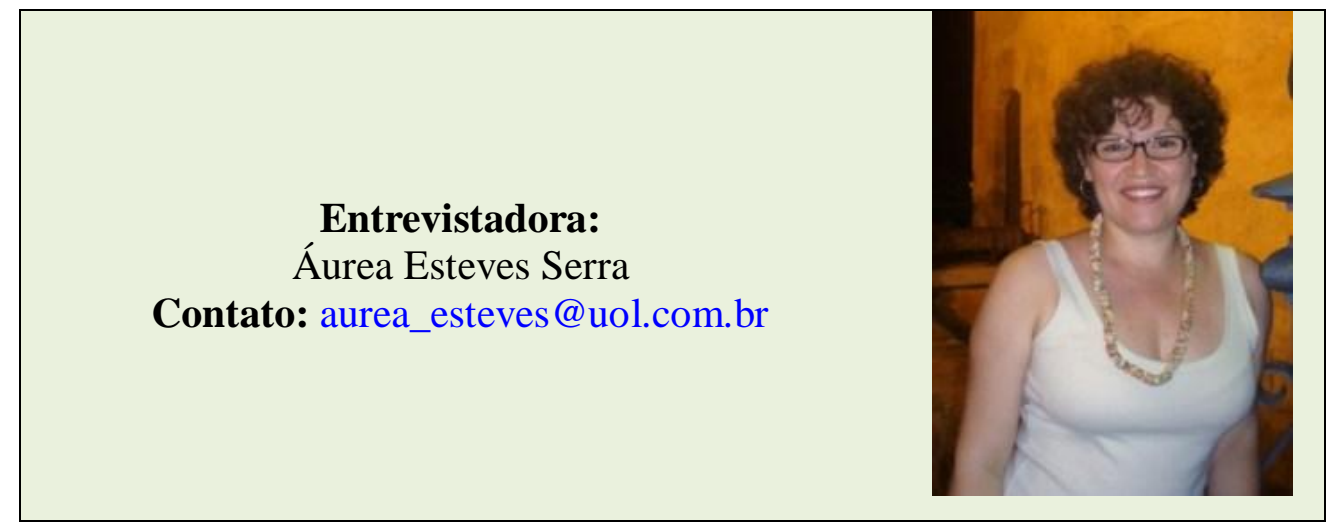

Áurea Esteves Serra é natural de Birigui/ SP. Licenciada em Pedagogia pelas Faculdades Integradas Toledo de Araçatuba, mestre em Educação pela Universidade Estadual Paulista - UNESP, Campus de Marília/SP. Atualmente doutoranda pela Universidade Estadual Paulista - UNESP, Campus de Marília/SP, na área de Políticas Públicas e Administração da Educação Brasileira, linha de História e Filosofia da Educação no Brasil;

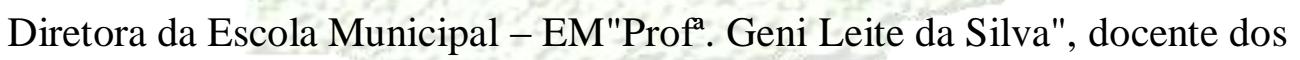
cursos de Pedagogia, Matemática e Administração da Faculdade de Ciências e Tecnologia de Birigui. Antes de seu ingresso no ensino superior e direção de escola, trabalhou durante vários anos como professora de Educação Infantil e Coordenadora Pedagógica na rede municipal de educação de Birigui/ SP e professora do ensino fundamental na rede estadual. 


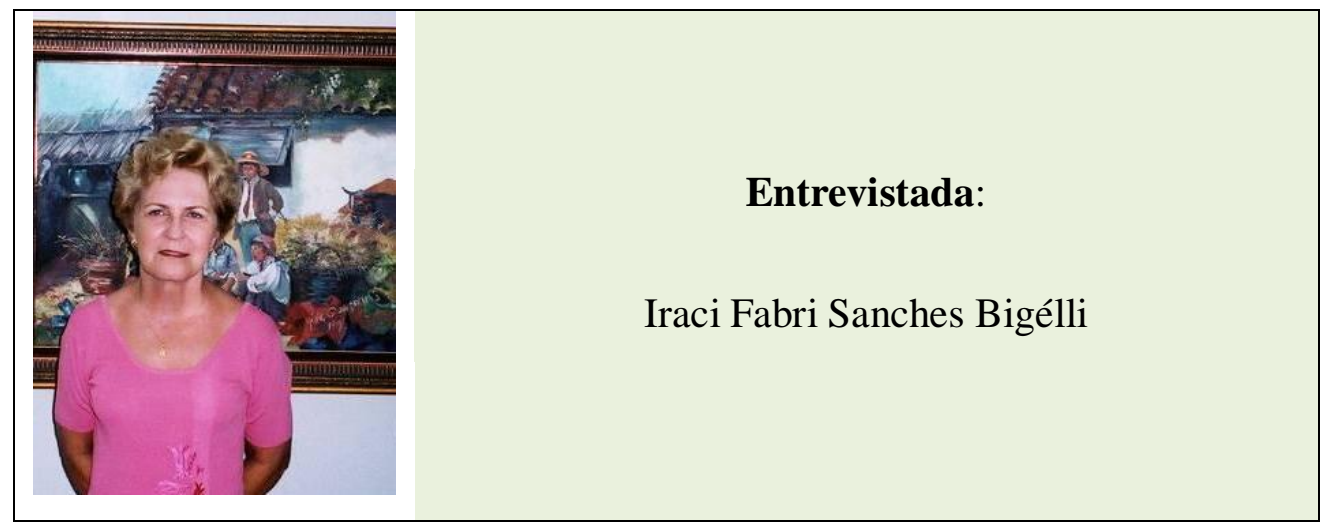

Natural de Birigui/SP. Formação: Curso Normal (1962); Curso de Aperfeiçoamento (1963); Curso de Pedagogia (Faculdade de Filosofia, Ciências e Letras de Penápolis (1974), com habilitações em orientação educacional $1^{\circ}$ e $2^{\circ}$ grau, administração escolar e supervisão escolar de $1^{\circ} \mathrm{e}$ $2^{\circ}$ grau, das disciplinas e atividades práticas dos cursos normais, Psicologia da Educação de $2^{\circ}$ grau, Sociologia da Educação de $2^{\circ}$ grau, Filosofia da Educação de $2^{\circ}$ grau. Campo de atuação. 1963 a 1988 - Professor I (aposentada); 1990 - Professor II (Ministrou aulas de metodologia no magistério); Vice diretora; 1991 a 1995 - Coordenadora Pedagógica. Especialista em alfabetização.

\section{Apresentação}

Esta entrevista é parte integrante do apêndice da dissertação de mestrado intitulada A formação do professor alfabetizador no IE "Prof. Stélio Machado Loureiro", Birigui/SP (1961-1976), defendida em outubro de 2004, no Programa de Pós-Graduação em Educação da Universidade Estadual Paulista (Unesp), Campus de Marília/SP, sob orientação da professora Dr ${ }^{a}$. Maria do Rosário Longo Mortatti desenvolvida no âmbito do Grupo de Pesquisa "História do Ensino de Língua e Literatura no Brasil" (GPHELLB) e a equipe executora do Projeto Integrado de Pesquisa "Ensino de língua e literatura no Brasil: repertório documental republicano" (PIPELLB), ambos coordenados pela professora orientadora e subdivididos em cinco linhas de pesquisa: 1) Formação de Professores de Língua e Literatura; 2) Alfabetização; 3) Ensino de Língua Portuguesa; 4) Ensino de Literatura; e 5) Literatura Infantil e Juvenil. 
A entrevista é uma espécie de depoimento sensível a respeito das perspectivas que se tinha no tempo das normalistas, das dificuldades que as mesmas encontravam e ainda do amor que tinham pelo ensino.

A relação da entrevista com o tema da pesquisa deve-se a um dos objetivos proposto para o trabalho de pesquisa: Quais os princípios teóricos subjacentes à proposta de formação do professor alfabetizador e a inovação educacional proposta para os Institutos de Educação do Estado de São Paulo? Para isso foram selecionadas ex-alunas normalistas, onde a entrevista foi gravada e transcrita.

\section{A entrevista:}

Áurea: No decorrer do curso normal e aperfeiçoamento, quais matérias tratavam do tema alfabetização?

Iraci: Olha, todas falam um pouquinho, sem citar a História da Educação que falava só dos pesquisadores, sem falar de que nós tínhamos Educação Moral, mas tanto a Didática, como a Prática de Ensino e aquelas matérias mesmo, que estavam relacionadas com a educação, falavam sobre alfabetização, todas falavam de alfabetização, [...], Didática, Metodologia, eram separadas e essas matérias e todas falavam.

Áurea: O que foi visto sobre alfabetização, nessas matérias?

Iraci: Olha, é, interessante o que foi visto. Faz muito tempo, eu me formei em 1962, faz muito tempo. Em 1963 eu fiz aperfeiçoamento, mas o que foi visto é como se deveria ensinar as crianças a ler e a escrever. E quais os métodos que nós poderíamos usar para ensinar as crianças.

Áurea: A senhora me falou em métodos, quais seriam esses métodos?

Iraci: Nós víamos o método de sentenciação, palavração, analítico e sintético, método de contos e muitos outros, nem me lembro quais. Todos os métodos foram bem enfocados e é interessante que foram desenvolvidos. 
Por exemplo, a nossa professora sorteava na classe alunos para dar aulas sobre com o método de contos, o método de palavração, o método de contar histórias, e assim nós íamos desenvolvendo esses métodos. Cada método era desenvolvido na prática, nas aulas de estágio por dois alunos, porque era impossível trabalhar toda classe com um método só.

Áurea: Então, o curso dava assim uma preparação muito boa, com relação aos métodos?

Iraci: Sim dava, muito boa, tanto teórica e prática, sim, pelo menos no início. Porque não dava uma prática para você sair de lá, uma professora sem dificuldade, não, nós saíamos de lá com dificuldades e cada um escolhia o seu método, e cada um trabalhava de acordo com o que melhor tinha, de empatia. Eu posso gostar mais de um método ou de outro e cada uma foi seguindo o seu.

Áurea: Então vocês conheciam o método na teoria e iam para a prática?

Iraci: Sim.

Áurea: Para trabalhar com o método?

Iraci: Sim.

Áurea: Como era essa prática?

Iraci: A nossa professora sorteava os alunos e dizia: "você vai usar o método de contar histórias". Então eu tinha que preparar uma história e que a classe participasse dessa história e saber contar histórias. Inclusive eu fui sorteada num desses, eu tinha que contar histórias assim, prendendo, seduzindo os alunos e fazendo com que eles participassem da história. E outros, então: o método, aquele de orações, método de contos, os alunos 
fizeram a aplicação desse método, o método de uma lição da cartilha, que é o analítico e sintético da cartilha que se usava na época. Uma aluna também foi dar aula sobre isso. E outros métodos de exposição, expositivo da aula de Geografia, História. Você expunha a matéria depois levava material didático, uma série de apetrechos que te facilitassem trabalhar e seduzir o aluno, porque o simples fato de você ser uma estagiária, uma aluna do curso normal já deixava os alunos, assim, alvoroçados, então você tinha que levar coisas para seduzi-los e aí então tentar o ensino-aprendizagem.

Áurea: Então, vocês iam com o plano de aula/ensino pronto?

Iraci: Pronto. Depois de expor a aula havia crítica de todas as alunas que ficavam no fundo, assistindo, havia crítica da nossa professora também e ela colocava todos para ler o plano, todos os alunos. Todas nós éramos mulheres, só um homem, e cada um falava sobre o plano e a relação com a aula, se alguma coisa era deixada de falar e estava no plano, ou era falada a mais. Existia uma crítica construtiva, era uma aula que ia servir para os demais alunos e a professora. Isso nós fazíamos.

Áurea: Antes de começar a alfabetizar faziam-se exercícios preparatórios?

Iraci: Ah! Existia sim, vários exercícios preparatórios, nós estudamos muito os do Lourenço Filho e muitos outros nós estudamos bastante e fizemos.

Áurea: Então, vocês estudaram os testes ABC, de Lourenço Filho?

Iraci: Sim, só que eu não me lembro muito mais, sabe? Eu vou ser honesta, eu sei que a gente estudou temporalidade, lateralidade, coordenação motora. Ah! Sensório mecânico, nós estudamos tudo, tudo, tudo daquilo, tudo o que foi possível nós tivemos o contato, e depois então como professora cada uma escolha o seu método. E seus exercícios. Eu me lembro bem que a 
gente, eu, particularmente, fiz uma seleção de exercícios. Em cada exercício tinha: o objetivo daquele exercício, inclusive, o inspetor escolar na época, não era supervisor, era inspetor, ele pediu para que eu fizesse um livro para ele, com todos os exercícios para serem dados e em cada exercício os objetivos que estavam ali dentro e ver se esses objetivos estavam de acordo com os objetivos seguintes, sabe? Foi um calhamaço muito grande que eu fiz e que eu entreguei na mão dele e ele falou que ia passar para as outras escolas, porque começava do mínimo da criança, porque nós sabemos que a criança vem principalmente na zona rural, não aqui, falando em cidade, na parte urbanística, mais na zona rural, as crianças têm pouco contato, e naquela época não tinha contato nenhum. Não havia televisão, não tinha, alguns não tinham nem rádio, saíam da escola e iam para a roça trabalhar. Então, que coordenação que eles desenvolviam? Só puxar enxada ou arrancar matinho, sabe? Alguns não conseguiam nem segurar o lápis, então nós tínhamos o período preparatório, uma parte em que fazia com os alunos ginástica com as mãos, com os braços, com as pernas, com a cabeça, com o pescoço, para um lado, para outro: Primeiro você usa um lado, o outro, depois você usa o esquerdo, direito, depois você usa as mãozinhas, fecha a mãozinha, abre a mãozinha, aponta os dedos, faz firme, firme. Eu começava com esta parte e o conhecimento da escola, sabe? Era preciso, porque a criança tinha medo, imagina você, hoje nós somos pessoas adultas, mas crianças de sete anos que nunca tinham adentrado na escola, eles vão, os pais colocam lá e eles ficam com uma desconhecida. Que medo? Como eles devem ter sentido medo, meu Deus. Então, eu tinha uma coordenadora pedagógica que falava que a professora de $1^{\text {a }}$ série tem que ser "escolhida a dedo", ela tinha que ser muito pacienciosa, humilde, pequena e alegre, para que as crianças não sentissem medo dela, sabe? Então ela falou que as professoras de $1^{\mathrm{a}}$ série teriam que ser escolhidas dessa forma e também com afinidade para alfabetização, para o início da alfabetização. Ela falava isso. Então, quando eu penso naqueles meus aluninhos, lá de Juritis, eu tinha 52 
alunos você sabe o que é Juritis? Que os pais colocaram na carteira e foram para a roça eu fico pensando quanto medo essas crianças sentiram! Então, o que eu fazia primeiro era mostrar toda a alegria de recebê-los, que eu ia ser a mãe deles na escola, se possível, que eles tinham só a mim para recorrer, eles não tinham mãe, pai que eu pudesse telefonar. Professora naquela época era tudo: pai, mãe, psicólogo, médico. Era tudo e era professor. Então eu pegava essas crianças, perguntava o nome, aqueles que conseguiam falar contavam alguma coisa das suas vidas, de sua casa, se tinham irmãos, se não tinham, do que gostavam, do que não gostavam e sempre era uma repetição, porque os alunos eram os mesmos, estavam sempre juntos e daí você tirava o material para trabalhar com eles e já conseguia deles a confiança. Lá em Juritis nós tínhamos quatro salas: a diretoria, a sala dos professores, a cozinha, os banheiros e tínhamos um terreno muito grande, onde nós, professores, plantávamos a mandioca, o milho, tinha pomar, tinha tudo, Então a gente ia brincar com essas crianças. Brincávamos de roda, brincávamos de tudo, de pega-pega, até que a criança adquirisse confiança em nós. "Essa mulher, essa pessoa, eu posso confiar é minha amiga", lá na cabecinha deles já colocavam isso. Não precisa falar isso, mas intrinsecamente estava aí, colocada a confiabilidade entre a professora e os alunos. E aí, então, nós começávamos com todos os exercícios e com os exercícios preparatórios, começava muito lentamente com desenhos. Por exemplo, se tinha lá o caminho do gatinho, tinha o gatinho que ia comer ou beber o leitinho, então era somente uma pequena curva pontilhada e nós falávamos tudo sobre o gatinho; cada um falava do gatinho que tinha em casa, de que cor era cada gato, sabe? Ver se eles conseguiam pintar o gatinho, o leitinho que cor que era, a cuia, porque naquela época eles usavam cuias, não era não pratinho como nós usamos hoje, essas coisas bonitinhas, a cuia de que cor era, tudo isso você trabalhava. Já falando sobre o gatinho, estou falando de Ciências. Da alimentação do gato, estou falando de higiene, estou falando de tudo. Você está entendendo? Quer dizer, havia 
necessidade que eles me falassem tudo o que sabiam sobre aquilo pra depois eu colocar mais alguma coisa em cima. $\mathrm{O}$ gato não bebe só leite. $\mathrm{O}$ gato também é um caçador, o gato é um felino, só que é doméstico. Eu falava muitas coisas para eles. Depois, então, que cor nós vamos pintar o gatinho? Você pode pintar o gatinho da cor que você quiser. Tem gato de pelúcia de todas as cores e você pode pintar o gato da cor que você quiser, mas de que cor é seu gato? É tal cor? Na vida real as cores são essas, mas na vida que tem por aí de promoção, comércio, existe gato de todas as cores, não importa a cor do gato. E cada um escolhia sua cor para pintar o gatinho e nunca foi tolhido; ah, você pintou seu gato de verde? Não e se ele via um gato verde na casa do amigo dele que era um brinquedo e daí? Ele gostou do gato verde, era verde, mas ele sabia que o gato da casa dele era carijó, amarelo, branco, preto, não faz mal, mas ele gostou de verde, para depois pegar o lápis preto e cobrir aqueles pontinhos, e aí eles ficavam cobrindo e tentando fazer na linha embaixo, faziam três linhas embaixo que estava só começada, e eles iam tentando fazer aquelas curvinhas, aprendeu tudo sobre o gato, aí a gente ia pra lousa ver quem sabia fazer. Aí eu ia lá, desenhava o gato, desenhava a cuia, aí eles me passavam que fazia certo a primeira linha, leve e solta, assim, já ia pro caderno eu já tinha desenvolvido alguma coisa neles, tinha desenvolvido o gato no inicio e o leite no fim. Já havia dado aula de ciências, higiene, e já tinha dado um pouco de coordenação motora e assim ia seguindo até o recorte e a colagem.

Áurea: Então tinha etapas a serem cumpridas?

Iraci: Etapas a serem cumpridas sim. E aí eu sei que eles faziam um trabalho muito lindo, o último trabalho que eu dava era recorte e colagem juntos. Primeiro era só recorte, depois era só colagem, esse último trabalho eles faziam recorte e colagem. Então, eu desenhava, passava no estêncil, no mimeógrafo uma folha pra cada um que continha uma cesta, uma cesta bem 
feita, pegava quase a folha inteira e na outra eu tinha várias flores, folhas, tudo o que vai numa cesta de flores. Entendeu? Aí eu dava primeiro a folha da cesta para eles pintarem, pra ficar bonita. Uma cesta que cor é uma cesta, pra que serve uma cesta, de cada coisa que você dava uma explanação, pra que serve, o que é, pra onde vai, enfim, você tem na sua casa, não tem, quem tem, quem deixa de ter, se não tem o que usa no lugar? Então você já desenvolvia vários conceitos na criança que ela não tinha conhecimento, lá na zona rural, porque aqui todos têm. E aí eles pintam esse trabalho, a cesta na cor que eles quisessem, pode pintar, mas geralmente todos pintavam a cesta da cor que é a cesta, eles não extrapolavam toda a imaginação, todos pintavam de marronzinho claro, marrom escuro, ah! De cinza, porque tem cesta envelhecida que é mais cinza, agora deixe essa folha de lado e vamos pintar essa folha, o que tem nessa folha? Aí eles olhavam e falavam: "tia tem uma rosa, tem um girassol". Tem? E aí nós falamos sobre as flores que existem e as que nós tínhamos na nossa escola também. Porque nós tínhamos jardim. Então, tem a flor de laranjeira, a flor disso, a flor daquilo, a de manga que era diferente, isso! E, no nosso jardim! Ah! tem girassol, tem cravo de defunto. Então eles identificavam cada flor e cada folha, cada tipo de folha. É a folha da laranjeira, a folha roseira. A partir disso, tinha dado outra vez Ciências, e feito uma relação entre o que de fato existe e o que estava no papel. E aí, então vamos pintar as flores, da cor que quisessem e as folhas também porque existe folha amarela, vermelha. Vocês podem ver no jardim, verde, da cor que vocês quiserem. Então, eles pintavam. Agora vocês vão recortar as flores e as folhas, tirem dessa folha e agora nós vamos colocar essas flores e tinha um laço também para por no cabo da cesta. É esse laço? O que é um laço? É uma fita. Pra que serve a fita? Ah, pra por na cabeça, pra amarrar trança, faz isso, faz aquilo, uma série de coisas na época. Mas serve também para enfeitar as coisas, amarrar numa caixa, amarrar no cabo da cesta e vocês podem pintar da cor que quiserem. Feito isso, feito à pintura, o recorte, agora vamos colocar as flores na cesta. 
E laço também, lacinhos, ficava um trabalho lindo, lindo. Lógico que eles pintavam fora do risco, cortavam meio tortinho, mas ficava maravilhoso o trabalho e aí você começava a alfabetizar. Antes desse período, durante o período preparatório eu já ensinava para meus alunos algumas palavras. De que você gosta mais? A da mamãe, então perguntava como era o cabelo da mamãe, tudo, o nome. Então vamos aprender a escrever mamãe? Vamos. Então, eu ia na lousa e escrevia mamãe com letra cursiva e aí eles faziam no caderno depois papai, depois tia, todos me chamavam de tia. Depois dia, eles já sabiam escrever o dia, vamos supor, a data de hoje vinte e três. Pronto depois vem mais uma, dia vinte e três de junho, pronto. Na outra semana, dia vinte e três de junho de dois mil e três. Sabe, ia na sequiência e eles iam copiando e iam todos os dias, mas eu não dava para escrever uma folha de papai, uma folha de mamãe. Nunca fiz isso. Escreva mamãe três vezes, porque mamãe é um símbolo maior na nossa cabeça. Então, esse símbolo maior eles iam conseguindo por no papel com a maior facilidade e eu já estava desenvolvendo a coordenação. E isso durava de vinte dias a um mês, o período preparatório.

Áurea: Além desse período preparatório quais os pré-requisitos para a criança ser alfabetizada?

Iraci: O pré-requisito é se a criança estava pronta. Pronta sim, sabendo pegar um lápis, sabendo apagar, porque tinha criança que apagava, rasgava tudo, sabendo o que era uma escola, quem era professora, quem era a diretora, tudo. Tendo o conhecimento do global.

Áurea: A idade também era levada em conta?

Iraci: Não, eu tive crianças de cinco anos que aprenderam a ler e escrever. Como eu tive crianças de 12 anos que não aprenderam. 
Áurea: Então, todas as crianças tinham direito a matrícula, independente da idade? Por exemplo, nessa sua classe lá em Juritis de 52 alunos, você tinha essa diversidade de idades?

Iraci: Sim. E com mais um detalhe, eu nunca me deixei levar pelo aluno, pela turma mais forte, eu sempre pegava do mais fraco, pra chegar ao mais forte, então enquanto eu trabalhava muito com esses mais fracos a gente dava outras atividades para aqueles que acabavam mais cedo. Então eles podiam pintar, recortar revistas, jornais. Eles faziam isso, livrinhos de história, quando eles ainda não sabiam ler, eles viam apenas as figuras que eu acho que é uma grande coisa, é uma leitura de mundo. Eles viam as figuras. Deixava eles levar para casa, e se a mãe sabia ler, lia, e eles chegavam no dia seguinte e contavam. Outra coisa que nós tínhamos também que e eu esqueci de te falar era a hora da novidade, primeira coisa, o que aconteceu ontem, depois que você saiu da escola? Aconteceu alguma coisa com alguém? Vocês foram passear? Foram brincar? Foram pescar? Foram pra um lado, foram pra outro? Aí desenvolvia a linguagem oral e da linguagem oral a gente partia para linguagem escrita.

Áurea: E qual o material indicado para a alfabetização? Que era indicado no curso para vocês?

Iraci: Você fala nos cursos aqui, no normal e no aperfeiçoamento. Sim. Bom, para alfabetizar, tirando esse do Lourenço Filho e outros que a Maria Ignêz nos ajudou bastante, também era a cartilha. Mas demorava-se muito para chegar na cartilha e a cartilha da época [...], eu fui alfabetizada pela Sodré. "Pata nada. Macaca má". Essas coisas e para os meus alunos, naquele ano, quando eu cheguei de licença gestante no primeiro ano já era a Caminho suave. A Caminho Suave rodou muitos anos, sabe? Roda ainda? (Ouvi dizer que sim). Jura? Nossa senhora, enquanto eu fiquei em Juritis eu fiquei com a Caminho Suave porque as crianças não podiam comprar então 
passava de irmão para irmão e os que não tinham a gente comprava e dava, aqueles que entravam e não podiam comprar. Então, essa Caminho Suave ela rodou muito mesmo. Era aquela que tinha, não tinha outra, nós não tínhamos escolha. Então o que nós tínhamos? Tínhamos os cartazes da Caminho Suave porque ela vinha com cartazes, ela vinha com os carimbos de cada lição "é agora que estou me lembrando" (risos). (Ela era completa então?) (risos). É completa para a época. (Para a época?) Para a época porque ela vinha com os cartazes, a gente comprava tudo separado, os cartazes, os carimbos, e eu tinha tudo isso. E depois de um período preparatório que na época era um período rico que nem todos faziam isso, nem todos faziam isso porque na época também não tinha mimeógrafo. Onde tinha mimeógrafo era na Delegacia de Ensino da época que era em Araçatuba cujo delegado era o seu Carijó. E como ele gostava muito de Juritis e gostava muito da nossa diretora que era a Mariosita, que é uma pessoa fabulosa. Ele tinha dois mimeógrafos na Delegacia e ela contou pra ele como eu fazia o meu período preparatório. Fazia de cinco em cinco vias. Eu comprava papel carbono e punha quatro folhas brancas entre eles e a de cima e ali eu fazia pra todos os meus alunos. Cada e não era apenas três, quatro folhas pra cada um não, no final desse período preparatório cada aluno tinha trinta, trinta e cinco folhas no seu prontuário. Tinha o prontuário do período preparatório. E ficava tudo arquivado, de cada aluno no final do dia, de cada aluno existia esse prontuário.

Áurea: Então você me disse que você conheceu as cartilhas Sodré e a Caminho suave? Lembra de mais alguma coisa, que tenha sido comentada no curso?

Iraci: No curso todas usavam essas cartilhas. Uma usava a Sodré, outra a Caminho suave (risos) e não tinha mais nada. Mais aí quando eu saí de Juritis eu fui para Glicério. Em Glicério eu me encantei com uma cartilha 
que eu vi, era a cartilha da Mimi, uma cartilha maravilhosa. Você já viu a Cartilha da Mimi? (Não). A cartilha da Mimi, que é uma macaquinha. E em cima daquela cartilha eu elaborei uma história desde a primeira letra até a última lição dando continuidade, sabe quando eu peguei a cartilha eu fiz uma história igual à tia desenhava na lousa, já dei um pulo eles desenhavam, liam a historinha que eu havia contado depois eles podiam contar outra que era a macaquinha era gostoso dar aula em cima da cartilha da Mimi, por incrível que pareça a cartilha passou a ser um material a mais, não o básico para a alfabetização como era a Sodré, a Sodré não, a Caminho Suave era o básico, era em cima daquela cartilha que você tinha que alfabetizar, inclusive os conteúdos vinham da Delegacia de Ensino, o que você tinha que dar, por mês em cada matéria e nós tínhamos um exame para as crianças no final do ano que vinha pronto da delegacia de ensino e que não era aplicado por nós professores. Nós nem ficávamos na classe, por exemplo, a gente, em Juritis pertencia a Glicério, a não podia ir lá aplicar para os nossos alunos o exame de aprovação ou reprovação. Você precisa ver os ditados que eram dados, com todas as dificuldades que tem a língua portuguesa e em matemática. Tínhamos quatro problemas, situações problemas, uma adição, uma subtração, uma multiplicação, uma divisão. Então eles tinham que ter noção exata do que era adicionar, subtrair, dividir, multiplicar, conhecer as tabuadas décor e salteada até o cinco na $1^{\mathrm{a}}$ série. Tinha exame de leitura.

Áurea: Você se recorda na Cartilha Mimi fugiu, qual era o método que ela abordava?

Iraci: Ela começava com a palavra, depois tinha as frases que é o conto, depois tinha palavras, depois terminava na silabação. Vamos supor o analítico, o sintético e volta para o analítico, e dali formava novas palavras, novas frases, novas histórias. A cartilha da Mimi era boa por isso, porque 
ele te dava aquilo lá e do lado daquilo ela dava vários exercícios que você podia mandar numa tarefinha para fazer em casa e de lá tirar novos exercícios para a criança.

Áurea: O que era considerado um aluno alfabetizado?

Iraci: O aluno que conseguisse ser aprovado nesse exame final, você entendeu? Esse exame que era aplicado por um diretor, um inspetor que vinha da Delegacia de Ensino, quer dizer, se ele fosse aprovado ali, era $2^{\mathrm{a}}$ série, se não fosse ele ficava na $1^{\mathrm{a}}$ série outra vez. E muitas vezes era uma pena porque a criança que sabia tanto ficava tão nervosa, e ia mal, ia muito mal no exame. Era um excelente aluno, mas a pressão que eles sentiam no exame, vou passar para a $2^{\mathrm{a}}$ série? Ou vou ser reprovado? Vinha uma pessoa de fora, com um papel diferente, apesar de que eu sempre dava para os meus alunos, tinha que ensiná-los o que era uma avaliação, o papel almaço pautado, o aluno tinha que saber o verso e o outro lado da página, ele tinha que saber por que se não ele começava aqui, virava e continuava e aqui e aqui desse outro lado, então ele tinha que saber então você tinha que treinar o aluno abrir o papel, a fazer, a trabalhar. Então mensalmente eram feitas as avaliações nesse papel almaço e os pais assinavam, viam os cadernos e as crianças de uma certa forma eram alfabetizadas não só pela cartilha. Assim a gente levava a criança também, não sei se seria construir, mas descobrir o que era desconhecido para ela, porque toda criança tem a linguagem oral, maior ou menor, e essa linguagem oral tem que ser transformada em linguagem escrita para registrar fatos etc. e tal, dar uma noção para a criança e sei lá, eu acredito que naquela época da cartilha Mimi, e mesmo a Caminho Suave a gente já dava isso para a criança, porque vamos supor, na cartilha Caminho Suave a gente ia dar a laranja, sabe eles traziam a laranja, o que era a laranja? É uma fruta, mas como se trabalha essa fruta, então eles sabiam o que era descascar? Eles faziam até salada de frutas, que de repente 
eu pensei que fosse uma manga eu pensei que fosse isso, ou não tinha laranja, minha mãe mandou essa... Tudo bem, vamos fazer e podia levar até para a nossa cozinheira que ela fazia, então eu acho que de uma forma um tanto quanto rudimentar sem o conhecimento do construtivismo a gente levava, dava para a criança condições de descobrir um pouco as coisas também - e não ficava só preso a cartilha. Não, porque eles terminavam a cartilha comigo e em agosto eu já dava o livro - até eu preciso encontrar o livro que te falei - já dei o livro e eles já começavam a trabalhar em cima de um livro de leitura, porque a Caminho Suave tinha o $1^{\circ}$ livro da cartilha, ou seja, você já trabalhava em cima de um livro, então, de setembro a dezembro eu já trabalhava com o livro. E também eu tinha sempre coleções de história em livrinhos que eu colocava no fundo da sala de aula, quem acabasse o trabalho, ia lá e pegava livrinho, depois contava aquela história, desenhavam a história. (E esses livros eram seus?) Meus, tudo meu, o estado não nos dava nada, nada. E era um núcleo, por exemplo, Juritis, um núcleo de tuberculosos, nós professores de lá, fomos convocados através do Diário Oficial pra fazer o Teste de Mantoux e também pra fazer o Raios-X dos pulmões para ver se a gente não tinha adquirido a doença e foi feito lá nos alunos também. E foi constatado com o Teste de Mantoux tuberculose e nós e que dávamos os medicamentos para os alunos e também aplicava-se uma vacina, se não acontecer nada, você não tem nada, mas se inflamar eles voltavam daí tantos dias e mediam pra ver o grau que estava avançado na criança o vírus da tuberculose. E levavam os medicamentos nominados, este pra tal aluno, este pra tal aluno e nós é que ministrávamos os medicamentos. Então eu vou até falar uma coisa aqui e talvez eu esteja falando coisas que você não vai acreditar, mas a alimentação..., eu depois descobri. Aplicamos o construtivismo aqui no Stélio onde eu fui coordenadora da escola padrão de PI e lá fala que a alimentação não tem nada a ver com a aprendizagem. Mas tem sim, um pouquinho tem. Lourenço Filho falava isso, se eu não estiver enganada. Eu tenho as idéias aqui, sabe aquela Coleção Idéias, eu 
tenho todas. Lá fala que não tem a ver, mas tem, como que uma criança com o vírus da tuberculose, que passa fome em casa, vai ter vontade de fazer alguma coisa na escola? É neste ponto que eu te falo, não diminuía a inteligência da criança, não, mas diminui a vontade da criança, de fazer as coisas, aí nós começamos a implantar, já tinha a sopa, nós começamos a passar no açougue levar osso, levava carne também, outro dava isso, aquilo, a sopa ficou enriquecida, as crianças começaram a revigorar, a gente fazia a sopa e mandava para casa delas, das pessoas que não tinham o que comer, então a alimentação faz diferença sim, não por causa da inteligência, por causa da vontade de fazer as coisas, da energia para fazer as coisas, entendeu? Não da inteligência, porque todo mundo é dotado dela, mais ou menos, mas é dotado né, até o que nós chamamos de deficientes mentais eles têm a sua inteligência, a gente não sabe se pra mais ou pra menos, nós que não sabemos lidar com eles, certo? Então eu acho que isso aí foi ajudando a criança a ficar mais forte, aprender com mais vontade.

Áurea: $\mathrm{Na}$ sua opinião, você considera que os conteúdos sobre alfabetização abordados nos curso normal e aperfeiçoamento foram suficientes para você dar aulas na $1^{\mathrm{a}}$ série? Por quê?

Iraci: Não, não foram suficientes, nunca em momento nenhum, qualquer curso nunca será suficiente, nunca, porque o progresso existe, existem novas descobertas, novos estudos, existe. E naquela época muito menos, não foi assim uma coisa que me deu embasamento para eu alfabetizar. Para que eu Iraci começasse a alfabetizar foi uma grande amiga que já era uma alfabetizadora e tanto e que me ajudou - Olha você começa assim, desse jeito... - bom, no $1^{\circ}$ ano foi de chorar né, promovi os alunos, mas chorei tanto, porque eu via que aquelas crianças precisavam aprender e eu não sabia como, de repente você fica naquela série, porque a minha vida inteira eu fui alfabetizadora, acho que só um ano eu peguei a $4^{\mathrm{a}}$ série pra voltar a 
aprender a divisão por decimais e aquelas coisas que eu já tinha esquecido, mas a vida inteira, aí você aprende a lidar e a criar, sabe, aí você vai a busca das coisas, aí eu fiz o $1^{\circ}$ curso de alfabetizadoras que teve em São Paulo, o primeiro da Emília Ferreiro. Eu fiz, foi quando eu comecei a estudar e (mas isso já em que ano seria?) Isso foi uns 2 anos antes de me aposentar, eu aposentei em 1988 eu devo ter feito esse curso em 1985. Formei-me em 1962, eu ingressei em 1967. Daqui de Birigui, da delegacia nós passamos em sete, no $1^{\circ}$ concurso de ingresso de Professor I, na época de professor de $1^{\mathrm{a}}$ a $4^{\mathrm{a}}$ série, nós passamos em sete, no $1^{\mathrm{o}}$ concurso, eu tinha saído do curso de aperfeiçoamento prestei o concurso e passei. E isso estudava também muito em Mirilópolis, em Psicologia que nos dava um embasamento muito bom de aprendizagem, (Mirilópolis?), Mirilópolis era um mexicano, nós estudamos, mexicano? Não lembro bem, tanta coisa que eu li, que eu fiz e depois foi todo esse pessoal, Emília Ferreiro e todos esses documentos, Piaget na Faculdade. Aí foi dando aquele embasamento e, por exemplo, eu tinha uma missão de um negócio que era visto e eu transportava pra outro, então meu professor de lingüística na época que era o José Fiorin. Você já ouviu falar do José Fiorin? Então o que ele explicava: ele olhava pra mim, você vai aplicar na sua sala de aula e vai me trazer o resultado e eu aplicava e levava o resultado pra ele, ele falava não estou falando pra vocês que é possível, é lindo, lindo, era isso e também aqueles cursos que nós tínhamos no SEROSP não sei se você ouviu falar que era em Araçatuba a gente tinha cursos todas as férias e esses cursos eram muitos bons e nos davam um embasamento melhor para gente poder pelo menos transgredir um pouco, dessa pasmaceira que era a vida, (Mas esses cursos do SEROSP foram logo após a formação do curso normal ou mais tarde?) É, eles saíram um pouco mais tarde e também porque eu ingressei mais tarde e só tinha direito a fazer, primeiro as professoras efetivas depois as vagas eram remanescentes e iam encaixando os outros. Você entendeu? Então se você tivesse oportunidade você fazia se não, não faria, aí você pegava dos outros pra 
poder melhorar sua prática. Porque, eu acho que é a obrigação de todo professor é melhorar a sua prática dia-a-dia embora eu te diga, até outro dia eu falei aí não sei com quem, não sei eu seria capaz de dar aula, mas se eu tiver meus aluninhos na frente outra vez eu acho que o bom educador é um giz, um apagador e seus alunos e vai embora. Inclusive uma vez aqui no Stélio, a Lídia Trevisam era minha coordenadora eu cheguei para Lídia e falei: Lídia, posso este ano trabalhar sem cartilha, ela falou, mas como que você vai trabalhar, eu falei: vou tentar tirar das crianças o assunto que eles vão preferindo e vou trabalhando com eles vamos ver por exemplo, se saiu o assunto bicicleta nós vamos trabalhar a palavra bicicleta, escrever bicicleta, desenhar a bicicleta, formar, ver as sílabas que a bicicleta é formada e depois formar novas palavras com aquelas sílabas e fui explicando pra ela, ela falou, sabe Iraci que é uma coisa muito boa só que eu vou te falar que você não pode trabalhar sem cartilha eu falei, mas porque? Porque os pais exigem a cartilha e ai? Eu vim pro Stélio em 1970, bem, em 1970 eu vim para o Stélio quer dizer trabalhei no $1^{\circ}$ ano, no $2^{\circ}$ ano e eu fui falar com ela, ela falou, eu falei você também pode me amparar e me ajudar, ela falou com todo prazer, só que tem que comprar a cartilha tem que ter a cartilha tem que ter a lição da cartilha, então eu segui a cartilha, é que eu não tenho, eu tinha um diário que eu encontrei, eu ia te mostrar, pra você ver que da lição que tava lá na cartilha eu tirava outra e punha na lousa para eles lerem e trabalharem tinha que ser feito isso porque eu acho que em tudo na nossa vida a gente quer ser seduzida, tem que gostar muito do negócio, se você não gosta, eu tenho que te seduzir, eu tenho que chamar você pra aquilo. E as crianças com medo, crianças que mal falavam, que não sabiam pegar no lápis, eu tinha que seduzi-los. Eu tinha que usar de mil artimanhas pra seduzi-los, eu já te falei que da cartilha Caminho Suave eu dava a lição da "barriga", do "cachorro", e a do "dado" eu pulava, pulava a do "dado" porque você vê o $\mathrm{d}$, a barriguinha é na frente e o b é atrás e aí começava a confusão, a lição do "dado" eu pulava já ia pra outra, pulava aquela lição, 
dava outra, pra depois voltar e tinha outra também era o p com outra letra não me lembro mais que acontecia a mesma coisa agora na cartilha da Mimi, não a cartilha da Mimi começava com Macaco, caco e sabe já era estruturada de acordo com as dificuldades para a criança não, não como se diz pra ela não se confundir que nessa eu ditava "data' ela escrevia "tata" certo? Então para a criança não se confundir já era feito assim, mas era feita uma história em cima dessa cartilha inteirinha, posso até te falar que a cartilha ela tem um, tinha uns, um, alguma coisa do período preparatório, e eu fazia com as crianças começava com a palavra avião. E eles me falavam, ah eu já fui no aeroclube, já fiz isso, já fiz aquilo e os tipos de aviões e desenvolvia o avião na cartilha e aí eu falava e punha um nome no piloto do avião estava sobrevoando uma ilha e caiu lá na ilha e quem o socorreu foi uma macaca e ele ficou muito amigo da macaca aí ele conseguiu sair de lá e levou a macaquinha e aí começava sabe? Então eu contava a história inteirinha, do começo ao fim (Pelos seus relatos então eu vejo que você trabalhou muito com histórias?) Ah sim (É o seu forte?) Era meu forte, é meu forte, eu gosto, porque eu leio muito e eu consigo transferir muito as coisas de um lado para o outro. Sabe? Eu leio demais, sempre li, a minha adoração era ler e como eu era pobre, não tinha livros quando criança, eu me lembro que eu lia os jornais que na época a gente comprava carne no açougue, eles passavam um papel branco, depois um jornal. E eu lia aqueles jornais e em algum lugar tinha um gibi, uma revista, eu pegava pra ler até que depois abriu uma biblioteca aqui no Roberto Clark quando eu estudava. Eu estudava a tarde e vinha toda a manhã ler livros. E assim eu li a obra de Monteiro Lobato inteirinha e outros livros. Então é muito fácil pra quem lê, e realmente sabe transferir as coisas, você conseguir trabalhar dessa forma porque você, não adianta você querer seguir uma coisa, você pega aí: a Iraci foi uma excelente professora de $1^{\text {a }}$ série aqui está o Diário dela siga esse Diário não adianta porque aqui no Diário só está os tópicos, as historinhas as coisas, tudo escrito, mas a minha maneira de colocar as coisas e o meu 
jeito de ser e a minha empatia, e a minha fidelidade para com os meus alunos e o meu amor para com os alunos e a empatia deles para comigo e a forma de eu escrever na lousa e chamar os alunos, está no Diário? Está no plano de aula? Não está. Está? Não está? (não está). Você pode desenvolver aquilo, chega lá, hoje é tal lição, pois eu não fazia assim, eu trabalhava antes, tanto assim é que eu entrava na aula vamos supor meio dia e meio, uma hora não me lembro mais, eu perdia mais de uma aula conversando com as minhas crianças e falando e indo e vindo e eles falando e eles colocando pra depois ir pra lousa pra depois eles pegarem o caderno e comigo não tinha caderno de Língua Portuguesa, caderno de Matemática, caderno disso, caderno daquilo, nós tínhamos o Diário Escolar e ali era desenvolvido porque de repente você estava dando uma lição da cartilha você dava ciências também e dentro das atividades que você poderia desenvolver, você colocava atividades de ciências ou você colocava atividades de História ou de Geografia, você entendeu? (Entendi) Eu tinha uma delegada aqui em Birigui, a dona Maria Antonia que ela falava assim pra mim: Iraci eu acho incrível você conseguir dar uma aula assim, você dá uma aula de uma lição e você espreme tanto a lição que ela vira que só sobra o bagaço porque dali você tira tudo, você integra tudo, você entrosa tudo, porque a vida não é feita por departamentos distantes, agora é leitura, agora é escrita, agora é matemática, não, você podia falar pra criança quantas palavras nós aprendemos hoje? Cinco, tia, muito bem e ontem? Duas, e qual a diferença entre ontem e hoje? Três quantas mais vocês aprenderam? Você não estava dando matemática? Não é maravilhosa a educação? (É). Eu adoro a educação, eu largaria tudo pra voltar a trabalhar com educação, mas eu já sou aposentada, aposentei em 88 trabalhei até 95, aí a reestruturação do ensino jogou o P1 fora do Stélio né, e acabou o P1, acabou a minha coordenação, acabou aquele contato gostoso que eu tinha com os professores, ensinar os professores a formular objetivos, tinha professora que chegava oh Iraci pelo amor de Deus como que faz um 
objetivo disso aqui? Então eu pegava e formulava, ajudava a montar planos que eu acho que o papel ah, não tem nada a ver né? (não pode falar) depois você tira. O papel de uma coordenadora é muito importante não é só coordenar, assim você vai fazer isso, você vai fazer aquilo porque essa semana nós vamos ter que desenvolver tal projeto, não o meu, eu acho que o papel da coordenadora é assessorar a direção sem sombra de dúvidas, tudo o que ela precisar, que estiver de acordo com a sua capacidade, assessorar os professores e fazer com que eles tenham a oportunidade de desenvolver um bom trabalho porque muitos querem e não conseguem, então chegava assim vamos fazer um projeto sobre algum tema, aí que jeito que faz, então vamos fazer juntos então no HTP, eu acho HTP é para a gente aprender tanto o texto, você estuda e você discute um texto, você está aprendendo, mas se você quer montar um projeto e que o pessoal não sabe montar você vai ensiná-los a montar um projeto, você também está estudando, não esta? (sim) Está ou não? (está) estamos estudando, eu estou falando com você, você está me conhecendo, você está me estudando, não está me estudando? (Estou). Você está me conhecendo, então eu chegava na minha sala, quando era $1^{\circ}$ Ciclo Básico, P1 e a gente desenvolvia projetos maravilhosos que foram pra FDE, então a $1^{\mathrm{a}}$ e $2^{\mathrm{a}}$ série, que projeto que vocês querem desenvolver? Vamos fazer alguma coisa diferente é escola padrão, então vamos aprender juntos? Aí, a professora Ivone Tosing que também é uma excelente alfabetizadora, inclusive está trabalhando até hoje, aposentou e está trabalhando em duas escolas por sinal, muito adorada no Instituto Noroeste, ela falou: Iraci você conseguiria ajudar a gente a montar um projeto, que começasse com uma musiquinha, falei: que música por exemplo? Aí eu peguei o plano de ensino de cada uma, porque eu tinha todas de $1^{a}$ série, falei olha vocês estão ensinando nesta época a rua onde mora, o bairro não é, ela falou é, é, isso mesmo, falei então vamos trabalhar cima da música "nesta rua, nesta rua tem um bosque que se chama que se chama solidão”. Falou isso, esta música está ótima e em cima dessa música 
nós montamos um projeto inteirinho que durou dois meses que foram desenvolvidos em todas as disciplinas e que as crianças aprenderam tudo. Ficou lindo o projeto em cima de uma música, como se pode fazer em cima de uma poesia, em cima daquele livro de história o Boi Azulão, você conhece? (O Boi Azulão, só de nome) Só de nome? (É) E as $3^{\mathrm{a}}$ e $4^{\mathrm{a}}$ séries desenvolveram um projeto que foi para o FDE. No curso que nós fazíamos com a professora Jane Sanches, da oficina pedagógica. Todas nós da escola padrão, nós íamos no curso, e nós fizemos com a Jane um curso de Língua Portuguesa. E ela pediu que cada grupo desenvolvesse um projeto; e eu como coordenadora falei: olha Jane, cada professor pode desenvolver seu projeto eu como coordenadora não posso pegar o meu professores $\mathrm{e}$ desenvolver um projeto só, cada série desenvolve o seu conteúdo. Ela falou pode sim. Aí nós tínhamos que apresentar esse projeto em novembro; se você quiser desligar pode desligar, se tiver atrasada você me fala heim, você não liga não heim, porque eu sou muito louca, apaixonada pela coisa, então todas nós montamos o projeto trabalhando o folclore... (Vou finalizar aqui). Ótimo, eu continuo falando do projeto sem gravar.

Áurea: Autoriza-me registrar o seu nome e divulgar o conteúdo desta entrevista?

Iraci: Pois não, Iraci Fabri Sanches Bigélli.

Áurea: Professora Iraci, muito obrigada, pela sua contribuição.

Iraci: Eu que agradeço a sua visita. Fez-me recordar coisas que foram caras, pra mim, foram muito ricas pra mim e coisas que me deram assim... Deramme muito prazer, viu, porque você pode até colocar aí, tirando os primeiros anos todos os outros anos a minha aprovação era 100\%, apesar de ter exames escrito e oral. Obrigada. 


\section{Como citar esta entrevista:}

BIGÉLLI, Iraci Fabri Sanches, por SERRA, Áurea Esteves. O percurso de uma alfabetizadora: formação e profissão. Revista ACOALFAplp: Acolhendo a Alfabetização nos Países de Língua portuguesa, São Paulo, ano 5, n. 9, 2010/ 2011. Disponível em: <http://www.acoalfaplp.net>. Publicado em: setembro de 2010 - março de 2011.

Recebida em fevereiro de 2009./ Aprovada em abril de 2009.

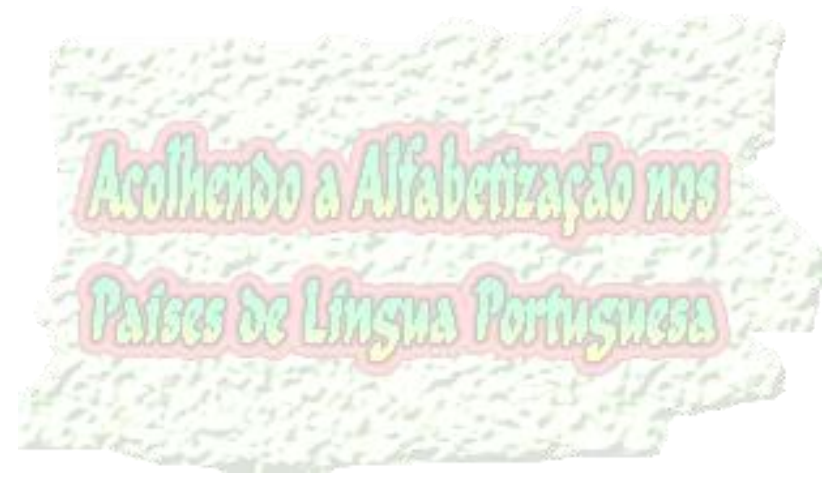

